九州大学学術情報リポジトリ

Kyushu University Institutional Repository

\title{
An Analysis of the Current Situation of the Small Peruvian Pisco Producers in the Canete Valley: A Case of Study Among Associated Farmers vs Non-associated Ones
}

Higuchi, Angie Luz

Laboratory of Food Marketing, Division of Industrial Organization of Agribusiness, Department of Agricultural \& Resource Economics, Graduate School of Bioresource and Bioenvironmental Sciences, Kyushu University

Yutaka, Tomoyuki

Laboratory of Agricultural Marketing, Department of Agricultural Economics and Management, Faculty of Agriculture, Kagoshima University

Fukuda, Susumu

Laboratory of Agricultural Marketing, Division of Industrial Organization of Agribusiness, Department of Agricultural and Resource Economics, Faculty of Agriculture, Kyushu University

https://doi.org/10.5109/16141

出版情報：九州大学大学院農学研究院紀要. 54 (2)，pp.535-540，2009-10-29. Faculty of Agriculture, Kyushu University

バージョン：

権利関係: 


\title{
An Analysis of the Current Situation of the Small Peruvian Pisco Producers in the Cañete Valley: A Case of Study Among Associated Farmers vs Non-associated Ones
}

\author{
Angie Luz HIGUCHI' ${ }^{1}$, Tomoyuki YUTAKA ${ }^{2}$ and Susumu FUKUDA* \\ Laboratory of Agricultural Marketing, Division of Industrial Organization of Agribusiness, \\ Department of Agricultural and Resource Economics, Faculty of Agriculture, \\ Kyushu University, Fukuoka 812-8581, Japan \\ (Received June 25, 2009 and accepted July 13, 2009)
}

\begin{abstract}
The Pisco is a superior quality clear brandy produced in southern Peru obtained from the fermented grape juice or must that has being exported to many countries around the world. The analysis is focused on the associated and non-associated current situation of the small Pisco Producers in the Cañete valleywhich is one of the most important Pisco production place in Peru-: the farmers who join the associations are very few comparing to the ones who work individually, but their willingness to belong to an organization is very high due to the benefits that they would receive through the cooperation. However, the fact of being associated or not does not impact significantly the current Pisco production volume and there is no presence of strong relationship between the dummy dependent variable association and the explanatory variable education as part of the socio-economic characteristics of the farmer.
\end{abstract}

\section{INTRODUCTION}

This paper is focused on analyzing the small scale Pisco producers in the Cañete valley who are generally artisan producers without high technology equipment. As a result, most of them are not able to produce in scale economy. Moreover, owing to the fact that the majority of farmers work individually, they do not have high production volume, neither enough power for negotiating with their suppliers nor their purchasers and do not have one uniform and standard quality. Therefore, to contribute to improve the competitiveness of the Cañete valley small Pisco producers regarding to the Pisco production, this study is required.

The analysis of the Pisco producers who are participating in an association or working individually, is centered in the Cañete Valley, where associated enterprises (which were established at the beginning of the 70s by the land reform) have been divided throughout the years and then disappearing due to the lack of long run term political vision, an unfavorable economic conjuncture, difficulties in organization experienced by the co-operatives and the will of the members to have access to private property. This paper attempts to comprehend the current situation of the small Pisco producers in the Cañete valley, if the fact of being associated impacts significantly the current Pisco production volume and if there is presence of strong relationship between the dependent dummy variable association and the explanatory variable education, because it is expected that higher

1 Laboratory of Food Marketing, Division of Industrial Organization of Agribusiness, Department of Agricultural \& Resource Economics, Graduate School of Bioresource and Bioenvironmental Sciences, Kyushu University

2 Laboratory of Agricultural Marketing, Department of Agricultural Economics and Management, Faculty of Agriculture, Kagoshima University, Kagoshima

* Corresponding author (E-mail: sufukuda@agr.kyushu-u.ac.jp) education influences the probability of participating in an association positively

\section{INITIAL DIAGNOSIS AND PERSPECTIVES}

\section{Pisco Production and Main Pisco export destina- tions:}

The national pisco production- both, the artisanal and the industrial production- reached 4,500.000 litres in 2007. It was calculated that by the end of the year 2008 , the production would reach to 5,600.000 litres.

Pisco Production (Millions of litres)

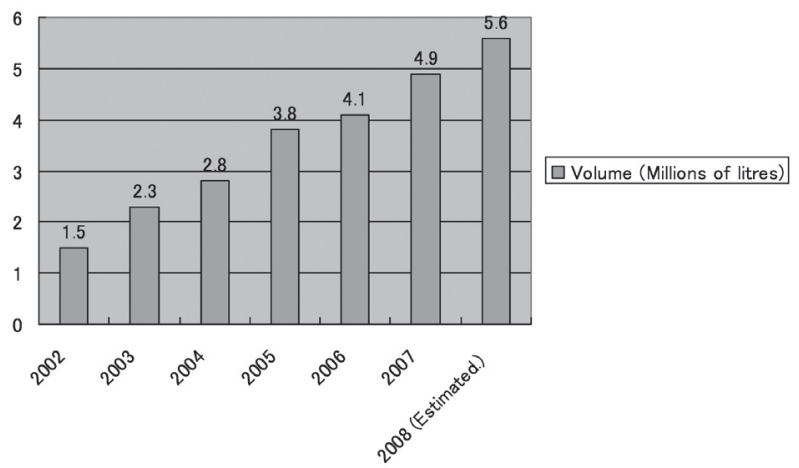

Fig. 1. Pisco Production (Millions of litres).

In the first five months of the current year, 2008, the Pisco exportation to the United States was US\$ 470,913, 36 percent more than the previous year's comparative period, when the exportation was about US\$ 345,450. The second market destination is Chile, whose purchase participation decreased from 28 to 11 percent (Pisco exportation was US\$ 54,126), with a falling of 44 percent in this period. The third destination country is Switzerland, followed by Panama, Spain and Canada. The new markets at the beginning of the year are: Thailand, 
United Arab Emirates, the Netherlands, Portugal, Honduras, El Salvador, Cuba and Brazil (The Peruvian Association of Exporters, 2008).

Peruvian Pisco Exportation by Destination Countries 2002-2007 (Litres)

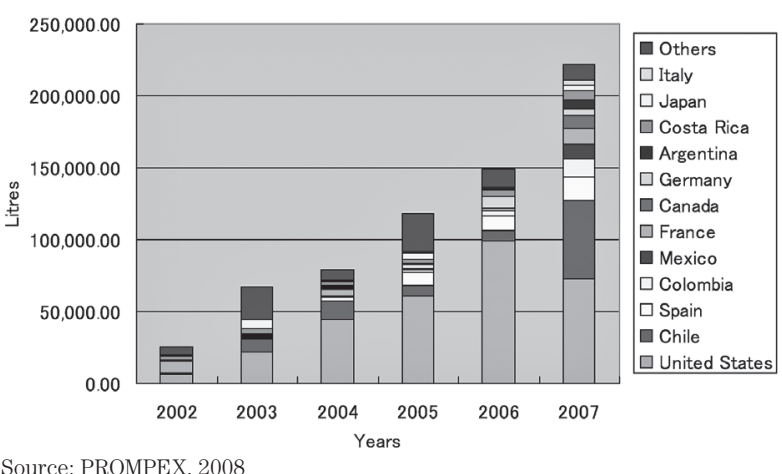

Fig. 2. Peruvian Pisco Exportation by Destination Countries in litres (2002-2007)

\section{Antecedents: Cooperatives disappearance in the Canete Valley}

The failure of the cooperatives in the Cañete Valley, and along the Peruvian coast- occurred for many political, economical and also social reasons. Between 1976 and 1979, all the valley cooperatives had economic surpluses, but since 1980 the cooperatives started to have deep losses and, finally, the government promoted the land division within the cooperatives, recommending their bankruptcy in order that other capable proprietors conduct properly the institution. By 1985 it was considered that around $60 \%$ of the coast cooperatives had been divided

In the year 1970, the agrarian Reform took the lands from 122 private farms in Cañete and organized them into 16 cooperatives destined to production, transforming the entire property structure. Ten years later, the 16 cooperatives were divided into 2000 new production units. While the production cooperatives were being transformed into service cooperatives, the economy liberation

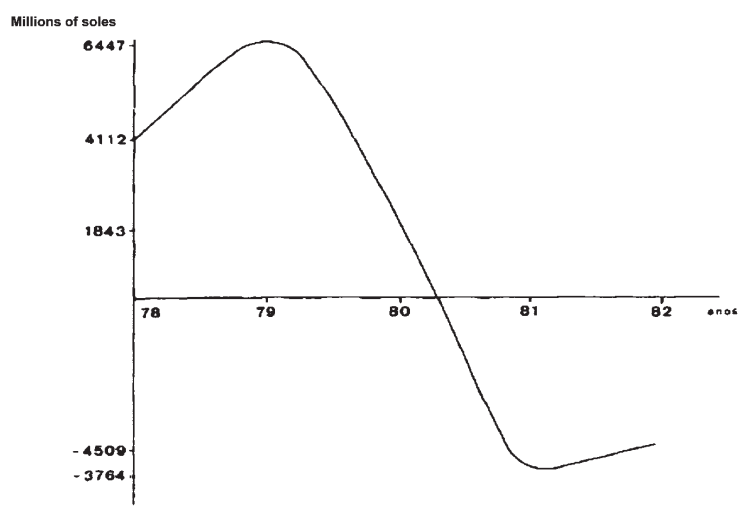

Fig. 3. Statement of total Losses and Gains Evolution of the Cañete valley cooperatives (1978-1982). impelled the middle-class sector, which previously was affected by the reform, and who started to diversify their activities and to control the commercial circuits (Auzemery and Eresue, 1986).

The current situation of the Associations in Peru:

Generally speaking, an association allows farmers to reach product volume, to minimize costs and improve quality. Moreover, in team work there is more fluency of ideas, the problems can be easily solved (better than working individually), compete in the market and negotiate the price. However, the associations in Peru are not marketing organizations, and therefore, do not collect, sort, grade or pack the product for the wholesalers as in other countries around the world.

The Peruvian associations just provide some technical assistance and training about fertilizers, land quality, pests, etc. Many distributors and buyers prefer to select and buy the raw material from the best producers in the zone rather than trust the services of the small farmers' groups like the associations (Author, 2008).

\section{MATERIALS AND METHODS}

A survey of the Pisco producers was carried out in March-April 2008 in the Cañete valley (this region is the second largest Pisco producer after Ica). Primary data was gathered by using a structured questionnaire in the study site through four conferences that the author and colleagues organized, focused just on the Pisco producers, being a very good opportunity for gathering them and making the survey. The questionnaire covered topics as socio-economic characteristics of households, farm production, purchase of raw material (grapes) for the production, Pisco production and prices, access to credit, if they participate currently in an association or not, and also, if in the future a Pisco cooperative could work or not. However, the questionnaire results had no statistical support for the quantitative analysis. As a result, a smaller sample (107 farmers) was used for the models usage and the rest of the observations and opinions were used for qualitative description respectively. Secondary data was also taken into account for the explanation of the current agriculture situation and the increasing Pisco exportation that was successfully started in the year 2002 in Peru.

For the results of this paper, three methods were used: The Cross Tabulation which displays the joint distribution of two or more variables as a contingency table in a matrix format for discrete variables, the equation of the production function that relates the quantity of output to the quantities of the inputs and also, the logistic regression which is similar to the linear regression model and is useful for situations in which you want to be able to predict the presence or absence of characteristics or outcome based on values of a set of predictor variables where the dependent variable is dichotomous. 


\section{MODELS RESULTS AND DISCUSSION}

\section{Cross Tables:}

More than $50 \%$ of the farmers answered that a Pisco Cooperative will work in Peru (the associated farmers and also the ones who have the desire to be associated) so that means that the Pisco producers have the willingness to join together for the common purpose of working together in order to improve their lives due to the benefits they can reach through cooperation.

Table 1. Cross Table (Status vs. Pisco Cooperative will work)

\begin{tabular}{lccc}
\hline & \multicolumn{2}{c}{$\begin{array}{c}\text { Pisco Cooperative } \\
\text { will work }\end{array}$} & Total \\
$\begin{array}{c}\text { Status (Associated } \\
\text { or not Associated) }\end{array}$ & Yes & No & $\begin{array}{c}\text { Number of } \\
\text { farmers }\end{array}$ \\
\cline { 2 - 4 } Associated & 48 & 23 & 71 \\
Non Associated & 12 & 3 & 15 \\
Total & 60 & 26 & 86 \\
\hline
\end{tabular}

Table 2. Cross Table (Desire to be associated vs. Pisco Cooperative will work)

\begin{tabular}{lccc}
\hline \multirow{2}{*}{$\begin{array}{c}\text { Desire to be } \\
\text { associated }\end{array}$} & \multicolumn{2}{c}{$\begin{array}{c}\text { Pisco Cooperative } \\
\text { will work }\end{array}$} & Total \\
\cline { 2 - 4 } & Yes & No & $\begin{array}{c}\text { Number of } \\
\text { farmers }\end{array}$ \\
\hline Yes & 36 & 17 & 53 \\
No & 10 & 6 & 16 \\
Total & 46 & 23 & 69 \\
\hline
\end{tabular}

Source: Author's survey, 2008

Table 3. Cross Table (Desire to be associated)

\begin{tabular}{lcl}
\hline $\begin{array}{l}\text { Variables } \\
\text { (Desire to be associated) }\end{array}$ & $\begin{array}{l}\text { Probability } \\
\text { Level }\end{array}$ & Correlation \\
\hline Monthly Income & 0.114 & No \\
Education Level & 0.787 & No \\
Age & 0.402 & No \\
Experience & 0.498 & No \\
Family Size & 0.614 & No \\
Technology & 0.064 & *Yes \\
Total Production area & 0.684 & No \\
Possess Machine or not & 0.951 & No \\
Buy raw material & 0.817 & No \\
Land Situation (Own or Hired) & 0.101 & $*$ Yes \\
Total Pisco Production & 0.899 & No \\
Pisco Grape production area & 0.364 & No \\
Adequate Installations & 0.827 & No \\
Capital (Own or third person) & 0.141 & No \\
\hline
\end{tabular}

However, due to the struggles that they have had in the past (the agrarian reform, the terrorism period, the government intervention, the El Niño phenomena, price controls, inflation, high taxes, food import with low prices, money devaluation, etc.) they answered that of course for improving their situation they would want to be associated and work in a Pisco cooperative in Peru but they also said that they need more government support, technical orientation, economic and security support, honesty of the members and capability of the people who will lead and integrate the cooperative, etc. (Author, 2008).

In the first table, the farmers who possess medium technology and own land situation (significance of 10\%) want to be associated. In the second table, on the other hand, the Pisco farmers who believe that a Pisco cooperative can work in Peru share certain characteristics as a high-school (medium) education level, have machine for distilling the pisco (alembic), buy grapes as raw material, and use their own capital (significance of 5\%) (Author's survey, 2008).

Table 4. Cross Table (Pisco Cooperative can work)

\begin{tabular}{lcl}
\hline $\begin{array}{l}\text { Variables (Pisco Cooperative } \\
\text { can work) }\end{array}$ & $\begin{array}{l}\text { Probability } \\
\text { Level }\end{array}$ & Correlation \\
\hline Monthly Income & 0.129 & No \\
Education Level & 0.025 & $\begin{array}{l}* * \text { Yes } \\
\text { (Significance: 5\%) }\end{array}$ \\
Age & 0.170 & No \\
Experience & 0.752 & No \\
Family Size & 0.676 & No \\
Technology & 0.942 & No \\
Total Production area & 0.714 & No \\
Possess Machine or not & 0.018 & (Significance: 5\%) \\
Buy raw material & 0.05 & $* *$ Yes \\
Land Situation (Own or Hired) & 0.564 & No \\
Total Pisco Production & 0.639 & No \\
Pisco Grape production area & 0.260 & No \\
Adequate Installations & 0.282 & No \\
Capital (Own or third person) & 0.05 & $\begin{array}{l}* * \text { Yes } \\
\text { Nignificance: 5\%) }\end{array}$ \\
\hline
\end{tabular}

Source: Author's survey, 2008

\section{Multinomial Logistic Model:}

The structural model to estimate a respondent's status (associated or not associated) was postulated as:

$Y i j=\beta_{0}+\beta_{1} i X_{1} i+\beta_{2} i X_{2} i+\beta_{3} i X_{3} i+\beta_{4} i X_{4} i+\beta_{5} i X_{5} i+e i j$ Where $\mathrm{Y} i \mathrm{j}=$ the dependent variable, scoring a value of 0 for non associated and 1 for an associated producer:

$\mathrm{X}_{1} \mathrm{i}=$ Experience (in Years)

$\mathrm{X}_{2} \mathrm{i}=$ Family size

$\mathrm{X}_{3} \mathrm{i}=$ Monthly Income 
$\mathrm{X}_{4} \mathrm{i}=$ Education

$\mathrm{X}_{5} \mathrm{i}=$ Total Area

e ij = Error term

This model was chosen because it is expected that higher education influences the probability of participating in an association positively because naturally, with more than average education they should know the theory that an association allows to have volume, minimize costs and improve quality. Moreover, working in a team work they can have more ideas, better solve the problems, compete in the market, and negotiate the price (Author, 2008).

In Block 1 is considered the variable "Monthly income" for being a significant variable among the other ones. The equation would be:

$\mathrm{Y}=-2.551+0506 \mathrm{X}_{1}$

Where $\mathrm{Y}$ is being associated or not (dummy variable) and $\mathrm{X}_{1}$ is the explanatory variable Monthly Income.

Table 5. Variable Income considered in the equation

\begin{tabular}{lcccccc}
\hline $\begin{array}{c}\text { Variables in the } \\
\text { Equation }\end{array}$ & B & S. E. Wald & df & Sig. & $\begin{array}{c}\text { Exp } \\
\text { (B) }\end{array}$ \\
\hline $\begin{array}{l}\text { Step 1(a) } \\
\text { Monthly Income }\end{array}$ & .506 & .241 & 4.427 & 1 & $.035^{* *}$ & 1.659 \\
$\quad$\begin{tabular}{l} 
Constant \\
\hline
\end{tabular} & -2.551 & .656 & 15.108 & 1 & .000 & .078 \\
\hline
\end{tabular}

** Significance: $5 \%$

On contrary, the removed factors (characteristics of the pisco farmers as experience in years, family size, education level and total area) do not present significant results.

Table 6. Variables not included in the equation

\begin{tabular}{clccc}
\hline $\begin{array}{c}\text { Variables not included } \\
\text { in the equation }\end{array}$ & & Score & df & Sig. \\
\hline Step 1 Variables & Years & .025 & 1 & .875 \\
& Family size & 1.616 & 1 & .204 \\
& Education & .034 & 1 & .855 \\
& Total area & 2.013 & 1 & .156 \\
\multicolumn{2}{c}{ Overall Statistics } & 5.469 & 4 & .242 \\
\hline
\end{tabular}

The Pisco farmers who belong to an association have to pay a member fee for receiving some information and training, so they must have a payment capacity that is translated in the monthly income. In addition, it is a tradition to be a member of this association because their parents, who were also farmers in the past, belonged to an association in the 1980s (Author, 2008).

\section{Production Function Model:}

A model for evaluating if the fact of "being associated or not" affects the total Pisco production volume, demonstrating that the association, in theory, as a group of people who have joined together in order to produce collectively, has a great influence in the current Pisco production volume in litres was necessarily required:

$$
\hat{\mathrm{Y}}=\mathrm{b}_{0}+\mathrm{b}_{1} * \mathrm{X}_{1}+\mathrm{b}_{2} * \mathrm{X}_{2}+\ldots \mathrm{b}_{7} * \mathrm{X}_{7}+\mathrm{U}
$$

Where:

$\hat{\mathrm{Y}}=$ Pisco production (Litres)

$\mathrm{X}_{1}=$ Grape area $(\mathrm{Ha})$

$\mathrm{X}_{2}=$ Association $(1=$ associated, $0=$ non-associated $)$

$\mathrm{X}_{3}=$ Labor $($ Male $=1$, Female $=0.8)$

$\mathrm{X}_{4}=$ Machine $(1=$ have alembiq, $0=$ not have $)$

$\mathrm{X}_{5}=$ Producers experience (Years)

$\mathrm{X}_{6}=$ Technology $($ Medium $=1$, Low $=0)$

$\mathrm{X}_{7}=$ Buy raw material $($ Yes $=1, \mathrm{No}=0)$

$\mathrm{U}=$ Error term

The variable that is important to analyze is "Being associated or not". Due to the technical assistance that the association members receive, it is expected that the Pisco production in litres can be increased (Author, 2008).

The production function equation would be:

$$
\begin{aligned}
\hat{Y}= & -37.89+142.01 X_{1}-83.05 X_{2}-2.72 X_{3} \\
& (177.50)(17.87) \quad(103.43)(21.33) \\
+ & 208.32 X_{4}+0.14 X_{5}-0.21 X_{6} \\
& (114.16) \quad(3.24) \quad(55.06) \\
+ & 320.18 X_{7}+U \\
& (94.51) \\
R^{2}= & 0.69, \quad n=54
\end{aligned}
$$

The t-value for the explanatory variables grape area and buy raw material (Pisco grapes) were 7.85 and 3.39 respectively which is highly significant at $1 \%$ level while having machine (alembic) is significant at $10 \%$. We can appreciate in the results that the variable "being associated or not" is not significant and, therefore, does not affect the Pisco production volume positively.

\section{CONCLUSIONS}

The small Pisco producers want to export their product as well, but they can not reach the required volume with a standard quality so, generally speaking, it is important to belong to a collective action group in order to be joined together for the common purpose of reaching the established volume, export together and share the benefits improving their lives. Pitifully, the Peruvian associations are not working well due to the failure of the cooperatives in the past, corruption inside the institutions, lack of education, etc. Moreover, the Peruvian associations are not marketing organizations that collect, sort, grade or pack the product for the wholesalers, they just provide technical assistance and basic training to their members, producing little amounts of Pisco in an individual way. However, the interviewed farmers (author's survey, 2008) have the willingness to work, produce and commercialize together, because producers who want to be associated and also who think that a Pisco cooperative can work in Peru are more than the $50 \%$ of the sample surveyed. 
It is expected that higher education influences the probability of participating in an association positively because with more than average education they know the theory that an association allows to have volume, minimize costs and improve quality. However, the results indicate that a continued participation in an association is not influenced by the level of education (there is no evidence of the presence of a strong relationship between the dependent variable "Association" and the explanatory variable "Education"). Nevertheless, to have more than an average "Income" is the main characteristic of the farmer who is joining an association nowadays because they have to pay a member fee and also it is a tradition for the producers to belong to an association (the famers' parents belonged in the past to the organization).

There is non-influence of the variable being associated in the current Pisco production volume and this is due to the associations' performance: they are just providing training and discussions in general topics related to the grape or Pisco prices as well as basic technical assistance in fertilizers, pesticides, grape prices, etc. In spite of this, the variables "area" and "buy raw material" have direct and great influence in the production (significance 1\%) because if the production area is expanded (in hectares) or if the farmers buy more grapes (in kilos), the volume of Pisco will be increased. Also, possessing a machine for distilling the Pisco, can increase the Pisco production volume (10\%) because there are not losses of raw material in the transportation or handling.

\section{POLICY IMPLICATIONS}

Peruvian farmers who are joining an association nowadays, due to many factors, do not trust in their companion members as a way for progressing together. The Peruvian agricultural institutions should work properly in order to have an appropriate organizational structure for taking advantage of the scale economies, information exchanges, marketing, technology, promotion activities and other services. Successful collective action hinges on four classes of determinants: the characteristic of the collective action (in the case of the associations in Peru they should work together in order to produce, sell and gain profits), the attributes of the group (in this case the members should work with ethical code that respects the equal citizenship, freedoms for progressing and also cooperation for the environmental sustainability in order to have good results in the future), the attributes of the institutional arrangements (respecting the peruvian constitution and the laws and also give the appropriate punishment if some action is unmoral or goes against the institution) and external influences (Gadzikwa et al., 2006).

For improving the performance of the current situation of the associations they have to set clear and detailed rules that govern the sharing of costs and benefits from the resource must be agreed upon by all participants. Second, congruence (the share of costs borne by each participant should be proportionate to the share of benefits they derive from the resource). Third, monitoring is essential for having a continuous improvement. Fourth, credible sanctions for deviators should be established ex-ante and punishment should be made public. Fifth, there must be a forum to resolve conflicts and discuss changes in rules in order to adapt the group to the external changes (Bandiera et al., 2005). Japanese institutions are a typical example around the world of a well organized system and the JA Japanese cooperative groups should be taken into account as a model for improving the situation in small scale of the Peruvian agriculture.

The success of collective action strategies intended to improve living conditions for rural populations and it depends on internal factors (values, standards of conduct, formal rules, mechanisms for enforcing rules and commitments, type of leadership), external factors (communication and cooperation among various stakeholders, linkages to "engines of sustainability" in collective actions) and contextual factors (in cultural terms, individualism versus solidarity; in economic terms, competition versus cooperation; and in political terms, autocracy versus democracy) (Ramirez et al., 2002). Education is the most important and powerful tool that the associations must take into account and can contribute to the improvement of the success of the collective action by the improvement of the external factors. For the farmers, it requires promoting and facilitating processes of social learning, through which rural groups, communities and organizations can gradually develop their own human and social capital as an instrumental strategy designed to achieve particular objectives that correspond to public goods. In Lima, through the department of Extension Service and Welfare, which belongs to the National Agrarian University, the associations can coordinate and make symposiums in order to get knowledge from the professionals who are studying there in order to transmit the information and settle the basis for progressing. Moreover, small groups are more likely to be successful cooperate in collective action, because the distribution of benefits is more likely to be unequal and, it is more likely that there is some individual who is willing to pay the full cost of the public good. Size, however, can also have direct effects. On the one hand, the institutional features that make collective action successful, such as monitoring, are more easily implemented in small groups (Bandiera et al., 2005).

Because the Peruvian Pisco producers work individually mainly and they have through the associations just simple training, there is not effect of being associated for having more Pisco volume. If the associations change their way of thinking as a group, trying to produce together, the Pisco production volume can be increased and they can start selling together, taking advantage of the closest main market that is Lima. A machine can be bought by the association with conjoint efforts in order to produce together (the result of the production function has $10 \%$ of significance if the farmers have their own machine for distilling, and therefore, the volume can be increased) so they can join their production, sell 
and distribute, gaining benefits by combined effects. A management tool as a cash flow was used in order to prove that if each member of the association cooperates with some amount of money, a machine for producing together can be bought rather than asking for a loan.

Finally, the Peruvian government should invest in proper research for implementing accurate policy implications and should consider the recommendations that the policy makers and researchers can give with the country economical possibilities. These recommendations can improve the agricultural sector and contribute with the economical situation of the country.

\section{REFERENCES}

Bandiera O., I. Barankay and I. Rasul 2005 Cooperation in Collective Action. Economics of Transition, 13(3): 473-498 Centro de Innovacion Tecnologica Vitivinicola (CITE Vid). 2004 La Uva y el Pisco: Potencialidades Productivas. Lima, Peru

Chirinos- Almanza, Alfonso. La Reforma Agraria Peruana. In "Nueva Sociedad", 21: 47-64

Di Falco, S., M. Smale and C. Perrings 2008 The role of agricultural cooperative in sustaining the wheat diversity and productivity: the case of southern Italy. Environmental Resource Economics. 39: 161-174

Eresue, M and C. Auzemery 1986 El proceso de parcelación de las cooperativas agrarias del valle de Cañete. In "French Institute for Andean Studies". Bulletin de l'IFEA 15(1-2): $179-205$
Fienberg, S. E. 1980 The Analysis of Cross-classified Categorical Data $2^{\text {nd }}$ Edition. M. I. T. Press, Cambridge, MA

Gadzikwa, I., Mc Lyne and Sl Hendricks 2006 Collective Action in Smallholder organic farming: A study of the Ezemvelo Farmers' organization in Kwazulu-Natal. South African Journal of Economics. 74: 2

Garcia-Sayan, Diego 1979 Apuntes sobre estado y agro en el Peru. In "Nueva Sociedad", 41: 30-47

Hernandez, R, T. Reardon and J. Berdegue 2007 Supermarkets, wholesalers, and tomato growers in Guatemala. Agricultural Economics. 36: 281-290

Nolasco B., Manuel 1986 El financiamiento de la Agricultura en el Valle de Canete. In "French Institute for Andean Studies". Bulletin de l'IFEA 15(1-2): 247-264

Pindick, Robert S., D. L. Rubinfeld 2001 Microeconomics, Fifth Edition. Prentice Hall International Inc., United States

Thiery, D 1986 Los sistemas de producción frutícolas en el valle de Cañete. In "French Institute for Andean Studies". Bulletin de l'IFEA 15(1-2): 207-246

Web pages:

National Agrarian University La Molina:

http://www.lamolina.edu.pe/proyectos/unir/html/rural/default.htm

Exporters association (ADEX): www.adex.org.pe

El Comercio Newspaper:

http://www.elcomercio.com.pe/ediciononline/HTML/2008-07-21/ exportaciones-pisco-crecen-pasos-agigantados.html Peruvian Pisco National Commission:

http://www.conapisco.org.pe/estadisticas.htm 